\title{
A computerized content analysis of communication styles of chairperson of public and private banks in India
}

\author{
Archana Singh ${ }^{1, *}$, KP Kanchana ${ }^{2}$ \\ ${ }^{1}$ Assitant Professor, Dept. of Operations and Decision Sciences, Birla Institute of Management Technology, Greater Noida, Uttar \\ Pradesh, ${ }^{2}$ Assistant Professor \& Area Chair(HR), Dept. of Human Resources and Organization Behaviour, Institute of \\ Management Studies, Noida, Uttar Pradesh, India \\ *Corresponding Author: \\ Email: archana.singh@bimtech.ac.in
}

\begin{abstract}
When we talk of Leadership and the effective communication of leaders, it is imperative for any organization. Leaders have manifold tasks in the organization as leadership is integrated with different levels like individual level, unit level and organizational levels. The purpose of this study is to examine, what is the effect of leadership communication in the organization. The purpose is also to find out to what extent the particular leadership behavior can impact the performance of public and private banks in India. The taken variables are based on the analysis of individuals, innovative role modeling recognition and monitoring and support for innovation.

Past researches have proven that in an endeavor to achieve the desired level of result and competence, it is that public sectors officials hunt for more effectual approaches of leadership, and challenge themselves to go for the prevailing models of the private sector organization. In the current study, we have investigated chairperson's messages to stakeholders through content analysis making use of DICTION software
\end{abstract}

Keywords: Effective communication, Private bank, Public bank, Content analysis, Diction.

\section{Introduction}

Every organization today is working in the turbulence of uncertainty and competition. They are striving hard to sustain their presence, grow and become a leader. But in this realm of uncertainty and turbulence there are certain organizations which have shown their mark with better control on their functions and operations and turn their operations into their competitive advantage. The leader is the one who is accepted by the masses but the process to make him acceptable is an element of 'beyond Leadership'. It is how effectively they are communicating their ideas down the line. In today's competitions the major responsibility of the organization is to achieve its economic development and also keep their employees motivated to sustain them in the organization. When we talk of the Public Sector Unit's, they constantly confront to the ever increasing demand in performance competence, their leadership techniques, to serve as per the expectations of the customers. As Budd, Thorp, and Donohue (1967) note, the most important behavior of a leaders is his or her form of behavior to communicate with others.

Performance assessment in organization are constantly confront to the ever increasing demand in performance competence, their effective leadership techniques, to serve as per the expectations of the customers(Moore 2002).What is constantly challenging for them are; how to communicate effectively so that their ideas propagate as per the expectations of the leaders. In response to the above said demands, recently many authors have addressed to the questions of effective leadership through effective communication in private and public sector organizations. For example, Doig \& Hargrove, 1990, Van Wart, 2003 summit to the relative scarcity of empirically based and wellarticulated public sector leadership research compared with the literature that currently exists for private sector organizations. Other endeavors were carried out by Horton, Farham, \& Hondeghem (2002) studied competency management in public sector organizations in the United Kingdom, Belgium, the Netherlands, Finland, France, Germany, Italy, Sweden, and Poland. The Economics Organization for Economic Cooperation and Development (OECD, 2001) has illustrated public sector challenges and approaches using leadership case studies from the United Kingdom, United States, Germany, Sweden, Norway, and Mexico. In the currents study, we have tried to measure the communication style at the top in public and private banks of India. In this study we have employed qualitative analyses of the chairperson message to stakeholders published in the Annual Report through content analysis and have tried to capture the significance of communication and is association with success in public and private sector banks and the difference in the behaviors in public sector from those found in private sector banks

\section{Rationale of the study}

Every organization has a different set of culture, work practices, environment, policies and the communication process the same vary in different types of banks. Therefore it is obvious that different types of banks will have different styles of communication from the top management. It's also been assumed that the public sector banks are more conventional in their 
viewpoint and so the leadership communication style will be more conformist and with more bureaucratic viewpoint. The managers in the banks follow tyrannical style of leadership and that is reflected through their communication style. Kaur (2004) established that the acuity of employees towards transactional and transformational leadership behavior across public and private sector banks and also intended to conclude if such perceptions differ depending on the socio demographic variables.

The Leaders who are concerned for the improvement in the relations with their employees time and again weigh up the link between effective leadership and communication. Jack Welch often emphasized on importance of communication excellence and he tried to eliminate clutters and jargons from General Electric (GE), where he served as the Chairman and CEO from 1981 to 2001.Communication being easily understandable and understood was vital.

Most of the companies and its management fail because of the failure in the communication process. The CEOs and the subordinates down the line are not able to align their communication properly. Taking an example of Michelle Peluso, CEO of Travelocity, Citigroup and Gilt, realized that only responsive leaders can motivate people. She was known to personally respond to every email of employees within 24 hours whether she is in the office or not. With this example we can understand the relationship between effective leadership through effective communication. By using effective communication, top management can play a dominant role in bringing employees' job satisfaction, productivity and commitment. An effective leader endows the way for the organization's success and steer the followers towards achievement of the desired goals.

It is vital that any communication to the stakeholders should be focused to the vision and values of the organization. Communication from the top management builds trust with followers and establish commitment with employees to the vision will see positive growth in the organization. According to Ireland and Hitt, strategic leadership theory advocates, "companies are a reflection of their top managers, and, in particular, of the chief executive officers" (p. 65). Leaders who fail to use effective communication skills may see a disgruntled workforce and confusion about the direction of the organization. While leaders must embody several qualities and characteristics, effective communication skills is one of the most pertinent to building a successful organization."
When we take a deeper insight about an organization's success we find that it is dependent upon the leadership style and also the flow of communication properly down the line.

\section{Structural Framework}

Private and Public organizations differ from each other in many aspects like goal convolution, organizational structure, work-related attitudes and values (Rainey \& Bozeman, 2000). The chairperson also have a different kind of constraints, accountability and sovereignty. Since not much research is done on the impact of effective communication from the chairperson's of public and private organization, we employed qualitative research design, as it can contextualize traits of leaders and constituents of leadership. In the research, latent content or semantic analysis of speeches is conducted through "Content analysis" on DICTION software. Content analysis is a qualitative research technique used to identify individual differences among communicators (Weber, 1990), the tool uses speech to study human cognition and communication (Alvesson \& Karreman, 2000). Political documents, corporate reports and scholarly treatises all use language to characterize a part of authenticity. Content analysis of texts offers much prospective profit, it is a research technique for the objective, systematic and quantitative description of the manifest content of communication. There are several software packages for conducting content analysis. Most of the software makes use of word frequency counts (Morris, 1994). We have used DICTION for conducting computer-aided qualitative analysis. DICTION was developed by a communication researcher with more focuses on the subtle power of word choice and verbal tone (Hart, 1984b). DICTION is popularly used for the evaluation of various associations in the area of qualitative research (Short \& Palmer, 2008). In the current study, qualitative analysis of how effectively Banks chairperson communicate to their stakeholders is executed, we used content analysis to validate the impact of communication prevalent in public and private banks in India. We measured communication by making use of five "master" variables available in DICTION. These master variables are composite dimensions and are built up on 33 discrete sub-dimensions. The master variables are like the constructs built on the vocabulary list. DICTION master variables were created with the rationale that "if only five issues could be raised of a given passage, these five would provide the most robust understanding (Hart, 2001). 
Table 1: DICTION Master Variables- Definition and Formula

\begin{tabular}{|c|c|c|c|c|c|}
\hline Variables & Certainity & Optimism & Activity & Realism & Commonality \\
\hline Definition & $\begin{array}{l}\text { words } \\
\text { demonstrating } \\
\text { firmness, } \\
\text { rigidity, and } \\
\text { completeness } \\
\text { and a } \\
\text { propensity to } \\
\text { articulate ex } \\
\text { cathedra }\end{array}$ & $\begin{array}{l}\text { Words } \\
\text { supporting } \\
\text { some people, } \\
\text { group, thought } \\
\text { or experience } \\
\text { or highlighting } \\
\text { their positive } \\
\text { involvements }\end{array}$ & $\begin{array}{l}\text { Words featuring } \\
\text { association, } \\
\text { transformation, } \\
\text { the execution of } \\
\text { thoughts and the } \\
\text { evasion of } \\
\text { inactivity. }\end{array}$ & $\begin{array}{l}\text { Words featuring } \\
\text { substantial, } \\
\text { instantaneous, } \\
\text { identifiable } \\
\text { issues that } \\
\text { influence } \\
\text { people's daily } \\
\text { lives. }\end{array}$ & $\begin{array}{l}\text { Words depicting } \\
\text { the consent } \\
\text { standards of a } \\
\text { group and } \\
\text { declining } \\
\text { personal style of } \\
\text { involvement }\end{array}$ \\
\hline Formula & $\begin{array}{l}\text { [Firmness + } \\
\text { Leveling + } \\
\text { Cooperative + } \\
\text { Perseverance] } \\
-[\text { Numerical } \\
\text { Terms + } \\
\text { Uncertainity+ } \\
\text { Self orientation } \\
+ \text { Diversity] }\end{array}$ & $\begin{array}{l}\text { [Admire + } \\
\text { Contentment + } \\
\text { Encouragement } \\
]-[\text { Culpability } \\
+ \text { Destitution + } \\
\text { Defiance }]\end{array}$ & $\begin{array}{l}\text { [Hostility + } \\
\text { Achievement }+ \\
\text { Statement }+ \\
\text { Action] - } \\
\text { [Cognitive } \\
\text { Terms }+ \\
\text { Obedience + } \\
\text { Adornment] }\end{array}$ & $\begin{array}{l}\text { [acquaintance + } \\
\text { Space } \\
\text { Consciousness } \\
+ \text { Sequential } \\
\text { Consciousness } \\
+ \text { Present } \\
\text { distress + } \\
\text { Human Interest } \\
\text { + Compactness] } \\
\text { - [Past Anxiety } \\
+ \text { Intricacy] }\end{array}$ & $\begin{array}{l}\text { [Vitality + } \\
\text { Collaboration + } \\
\text { Bond] - [Range } \\
+ \text { Elimination + } \\
\text { Emancipation] }\end{array}$ \\
\hline
\end{tabular}

These variables help an organization (bank) in examining the reflections of possible effects upon its performance. Within the scope of the study; Certainty, Optimism, Activity, Realism, Commonality were discussed in theoretical background section.

\section{Theoretical Background}

Certainty: "The 'knowing' of some details in a risky situation is enough of a factor to influence 'toward' behavior. Given that leaders are responsible for leading change or working on a myriad of projects that don't always have a clear-cut path to a desired outcome; leaders create situations fraught with risk and ambiguity. "It is believed universally that the culture of the company brings certainty. It's the USP which cannot be copied by the competitors, rest can be.

Activity: The successful communication of strategy in the organization ensures that the organization is adopting the changes rapidly. It also provides the conviction of apparent time limit and goals. Along with it there is transparency in the in the associated roles and responsibilities.

Many studies time and again haveshown that most of the strategies fail at the execution stage because leaders are not able to communicate effectively about their vision down the line. The successful organization, often particularly once in a year convene their top executives across the globe and embark their strategist to brainstorm and develop innovative strategies to enter the blue ocean, widen market share, generate more profit, and bring out positive changes in some aspect of the business. For the success of the strategy it is imperative that the strategy should be highly directorial in nature.
Optimism: It is believed that the Optimistic individuals focuses more on the problem solving strategies than the pessimistic individuals who keep on playing the blame game or is in the mode of withdrawal. Optimism is the belief that every action will give the positive results. It's a generalized expectations by the leaders of the company. They conceptualize that people in general anticipate that things will move in their way and assume that they will have more desirable results.

Optimism in the workplace could be a very positive force in the workplace. For example, optimists may be motivated to work harder; be more satisfied and have high morale; have high levels of aspiration and set stretch goals; persevere in the face of obstacles and difficulties and make attributions of personal failures and setbacks as temporary, not as personal inadequacy.

Seligman, the father of positive psychology, believes that optimist people, facing with failures and success, act as following:

1. The assumptions, "I can succeed in different areas".

2. The constant assumption, "I can constantly succeed in this area".

3. The success is attributed to their internal capabilities; "my own capabilities and efforts led to my success".

4. Failures are attributed to the specific external and inconstant factors (Luthans,Larson,2006:121)

5. The realistic optimism always plays have a significant role in helping the companies to stand with the contingencies

Realism: The various researches interprets that the possession of a few traits of leadership may not be enough for making the organization successful .Rather 
the success of the organization very much depends upon the effective leaders who are different from others in certain traits viz-a viz the effective communication skills, to lead from front, integrity, self-confidence, honesty, cognitive ability, and strong domain language.

Commonality: Leaders are said to be the prime key for the ethical guidance for employees in an organization and the effectiveness lies in the way it is communicated either verbally or non-verbally.

Hence the leaders' effective communication skills in all the arena who brings holistic changes in the performance of the organization. Transformational leaders inspire, energize, and intellectually stimulate their employees.

Focus to the banks particularly the leadership communication skills exhibited in public and private banks we find that a clear demarcation in the functioning of public and private sector banks. Mostly while private firms usually have clear instructions and guidelines with shareholders as the central group of players, we find that the public sector organizations are more discrete in their functioning.

It is also assumed that the performance information used in public sector organizations are less intensive, more accountable and more in a symbolic way to achieve partially incompatible goals, whereas in private sector organizations the performance information is expected to be more intensive and rational. The performance information of these systems cascade down within the organization (Brignall and Modell, 2000), argue that in case of a dominant stakeholder, performance information use may be more functional.

\section{Objective and Hypotheses}

The objective of the research is to find if there is a difference in the communication style of chairperson of public and private banks as exhibited in their communication through Chairperson's speech published in Annual reports to stakeholders.

For the study we congregated annual reports of public and private sector bank, but it did not include the co-operative bank or foreign private banks. In public domain, 25 chairperson's message of public sector banks was available in their annual report for the year 2016 . Whereas for private sector bank, 59 chairperson's message was available. For keeping the sample size equal for both the groups, we used random sampling method to select 25 private sector banks from the list of 59 private sector banks. Each chairperson message we analyzed through content analysis, so as to have an understanding of the choice of words and measure the master (manifest) variables which they practice in written communication.

Following hypotheses are framed for data analysis:

H01: There is no significant difference in the Activity aspect between private and public sector bank as exhibited by chairperson's message.

H02: There is no significant difference in the Optimism aspect between private and public sector bank as exhibited by chairperson's message.

H03: There is no significant difference in the Certainty aspect between private and public sector bank as exhibited by chairperson's message.

H04: There is no significant difference in the Realism aspect between private and public sector bank as exhibited by chairperson's message.

H05: There is no significant difference in the Commonality aspect between private and public sector bank as exhibited by chairperson's message.

\section{Analysis of Data and Results}

Content analysis of chairperson's message to the stakeholders was conducted for both the groups, public and private sector bank. Analysis of data was grounded on the constructs of effective communication and was determined by the problem statement.

The Diction software tracks and counts the use of words in the input text and produces a standardized score for each of the master variables.

Table 2 exhibit composite scores and standard scores for a few public and private bank's chairperson message for the five manifest variables. Like this the composite score for all the 50 selected banks are calculated on Diction.

Table 2: Composite Scores Generated by Diction 5.0 (2000) for the Dimension

\begin{tabular}{|l|l|c|c|c|c|c|}
\hline & & Activity & Optimism & Certainty & Realism & Commonality \\
\hline \multirow{2}{*}{$\begin{array}{l}\text { Standard } \\
\text { scores }\end{array}$} & Low & 46.74 & 46.37 & 46.9 & 46.1 & 46.86 \\
\cline { 2 - 7 } & High & 55.48 & 52.25 & 51.96 & 52.62 & 52.28 \\
\hline Bank type & Bank Name & \multicolumn{5}{|c|}{ Composite Scores } \\
\hline Private & Axis Bank Ltd. & $40.95^{*}$ & $53.56^{* *}$ & $43.98^{*}$ & 49.87 & 50.8 \\
\hline Private & DCB Bank Ltd. & 51.11 & $53.59^{* *}$ & 47.7 & $45.53^{*}$ & 51.22 \\
\hline Private & $\begin{array}{l}\text { The Federal Bank } \\
\text { Ltd. }\end{array}$ & 51.65 & $55.35^{* *}$ & 46.97 & 48.58 & 50.38 \\
\hline Private & Yes Bank Ltd. & 48.6 & $53.52^{* *}$ & 48.62 & $44.68^{*}$ & 49.64 \\
\hline Private & $\begin{array}{l}\text { Dhanlaxami Bank } \\
\text { Ltd. }\end{array}$ & 50.36 & $53.52^{* *}$ & $44.02^{*}$ & 49.15 & 49.66 \\
\hline Private & $\begin{array}{l}\text { Karur Vyasa bank } \\
\text { Ltd. }\end{array}$ & $40.95^{*}$ & $53.56^{* *}$ & $43.98^{*}$ & 49.87 & 50.8 \\
\hline
\end{tabular}




\begin{tabular}{|l|l|l|l|l|l|c|}
\hline Public & Bank Of Baroda & 50.28 & 51.33 & 50 & 47.73 & $46.01^{*}$ \\
\hline Public & Bank Of Maharashtra & 51.72 & 50.32 & $40.79^{*}$ & 46.4 & 50.84 \\
\hline Public & Vijaya Bank & 50.08 & $57.41^{* *}$ & 49.86 & $43.15^{*}$ & 48.17 \\
\hline Public & $\begin{array}{l}\text { United Bank Of } \\
\text { India }\end{array}$ & 53.55 & 51.85 & $41.81^{*}$ & $43.63^{*}$ & 49.15 \\
\hline Public & Syndicate Bank & 51.72 & 50.32 & $40.79^{*}$ & 46.4 & 50.84 \\
\hline Public & State Bank of India & 52.12 & 49.76 & 47.88 & $44.54^{*}$ & 48.27 \\
\hline Public & $\begin{array}{l}\text { Punjab National } \\
\text { Bank }\end{array}$ & 52.14 & 49.4 & $42.25^{*}$ & $45.79^{*}$ & $45.86^{*}$ \\
\hline
\end{tabular}

* Denotes composite score less than the standard value range

** Denotes composite score more than the standard value range

To test the 5 manifest variables viz., Activity, Optimism, Certainty, Realism and Commonality for the two populations viz., Public and Private banks we used "independent sample-t test" to test the framed hypotheses. Also F test of sample variance is performed to find if the two populations have equal variance.

\section{Table 2: Group Statistics}

\begin{tabular}{|c|l|c|c|c|c|}
\hline & Bank Type & N & Mean & Std. Deviation & Std. Error Mean \\
\hline \multirow{2}{*}{ Activity } & Private Bank & 25 & 47.2700 & 5.00264 & 2.04232 \\
\cline { 2 - 6 } & Public bank & 25 & 52.6730 & 1.85876 & .58779 \\
\hline \multirow{2}{*}{ Optimism } & Private Bank & 25 & 53.8500 & .73534 & .30020 \\
\cline { 2 - 6 } & Public bank & 25 & 53.6930 & 4.95773 & 1.56777 \\
\hline \multirow{2}{*}{ Certainty } & Private Bank & 25 & 45.8783 & 2.13015 & .86963 \\
\cline { 2 - 6 } & Public bank & 25 & 44.5660 & 4.10643 & 1.29857 \\
\hline \multirow{2}{*}{ Realism } & Private Bank & 25 & 47.9467 & 2.26975 & .92662 \\
\cline { 2 - 6 } & Public bank & 25 & 45.2310 & 2.01248 & .63640 \\
\hline \multirow{2}{*}{ Commonality } & Private Bank & 25 & 50.4167 & .65059 & .26560 \\
\cline { 2 - 6 } & Public bank & 25 & 48.5610 & 1.66792 & .52744 \\
\hline
\end{tabular}

Table 3: Independent Samples Test

\begin{tabular}{|l|c|c|c|}
\hline \multirow{2}{*}{} & \multicolumn{2}{|c|}{ Levene's Test for Equality of Variances } \\
\cline { 3 - 4 } \multicolumn{2}{c|}{} & F & Sig. \\
\hline Activity & Equal variances assumed & 14.687 & .002 \\
\hline Optimism & Equal variances assumed & 7.758 & .015 \\
\hline Certainty & Equal variances assumed & 8.887 & .010 \\
\hline Realism & Equal variances assumed & .216 & .649 \\
\hline Commonality Equal variances assumed & 2.023 & .177 \\
\hline
\end{tabular}

Table 4: Independent Samples Test

\begin{tabular}{|c|c|c|c|c|c|c|c|c|}
\hline \multirow{3}{*}{\multicolumn{2}{|c|}{ 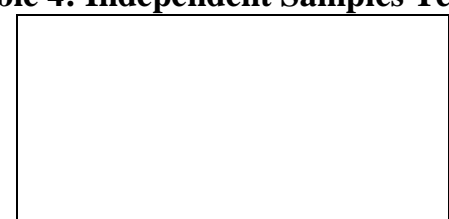 }} & \multicolumn{7}{|c|}{ t-test for Equality of Means } \\
\hline & & \multirow[t]{2}{*}{$\mathbf{T}$} & \multirow[t]{2}{*}{ df } & \multirow[t]{2}{*}{$\begin{array}{c}\text { Sig. } \\
\text { (2-tailed) }\end{array}$} & \multirow[t]{2}{*}{$\begin{array}{c}\text { Mean } \\
\text { Difference }\end{array}$} & \multirow[t]{2}{*}{$\begin{array}{l}\text { Std. Error } \\
\text { Difference }\end{array}$} & \multicolumn{2}{|c|}{$\begin{array}{l}\text { 95\% Confidence } \\
\text { Interval of the } \\
\text { Difference }\end{array}$} \\
\hline & & & & & & & Lower & Upper \\
\hline \multirow[b]{2}{*}{ Activity } & $\begin{array}{l}\text { Equal variances } \\
\text { assumed }\end{array}$ & -1.971 & 14 & .069 & -2.40300 & 1.72504 & -1.10283 & 7.29683 \\
\hline & $\begin{array}{l}\text { Equal variances } \\
\text { not assumed }\end{array}$ & -2.125 & 5.840 & .048 & -2.40300 & 2.12522 & 1.63787 & 8.83187 \\
\hline \multirow{2}{*}{ Optimism } & $\begin{array}{l}\text { Equal variances } \\
\text { assumed }\end{array}$ & .076 & 14 & .940 & .15700 & 2.06520 & -4.27241 & 4.58641 \\
\hline & $\begin{array}{l}\text { Equal variances } \\
\text { not assumed }\end{array}$ & .098 & 9.649 & .924 & .15700 & 1.59625 & -3.41731 & 3.73131 \\
\hline \multirow{2}{*}{ Certainty } & $\begin{array}{l}\text { Equal variances } \\
\text { assumed }\end{array}$ & .720 & 14 & .483 & 1.31233 & 1.82288 & -2.59737 & 5.22203 \\
\hline & $\begin{array}{l}\text { Equal variances } \\
\text { not assumed }\end{array}$ & .840 & 13.864 & .415 & 1.31233 & 1.56286 & -2.04277 & 4.66743 \\
\hline
\end{tabular}




\begin{tabular}{|l|l|c|c|c|c|c|c|c|}
\hline \multirow{2}{*}{ Realism } & $\begin{array}{l}\text { Equal variances } \\
\text { assumed }\end{array}$ & 2.495 & 14 & .026 & 2.71567 & 1.08855 & .38096 & 5.05038 \\
& $\begin{array}{l}\text { Equal variances } \\
\text { not assumed }\end{array}$ & 2.416 & 9.638 & .037 & 2.71567 & 1.12412 & .19817 & 5.23316 \\
\hline Commonality & $\begin{array}{l}\text { Equal variances } \\
\text { assumed }\end{array}$ & 2.580 & 14 & .022 & 1.85567 & .71918 & .31318 & 3.39815 \\
& $\begin{array}{l}\text { Equal variances } \\
\text { not assumed }\end{array}$ & 3.142 & 12.676 & .008 & 1.85567 & .59054 & .57655 & 3.13478 \\
\hline
\end{tabular}

Table 2 represents the descriptive statistics of the five manifest variables for public and private sector banks. Table 3 represents the calculation of Levenes Test for testing the equality of variances. From Table 4 represents the calculation of Independent sample t test, to calculate if there is any significant difference in the two populations. From table 4 we interpret the results that for manifest variable activity, realism and commonality there is a significant difference between private and public banks. The chairperson's messages of public bank demonstrate more activity as compared to private bank. On the other hand, the aspect of realism and commonality are better exhibited in private banks chairpersons' message. There is no significant difference in certainty and optimism for the two types of banks. Also from table 2, we detect that optimism is really high in the messages of both the public and private bank.

We have inferred that it is very important to have effective optimistic leadership along with strategic vision for the success of any company.

\section{Conclusion}

It is difficult to estimate the reliability of qualitative content analysis due to defective and prejudiced collection of information/data and/or deficient ways of investigation of the information (Elo et al., 2014). Content analysis helps in systematically exploring language/communication in quantifiable variables. With the study we conclude that the chairperson of public sector banks are more optimistic and realistic in their communication to stakeholders. The success of the public sector banks depend on the leader's choice of words, values and the ability to craft confidence and trust in the organization inculcating in every employee the ability to trust, optimistic and being realistic. Public sector banks are more certain about their activities, values and culture. The communiqué demands optimism and inspiration. Not only this but it is again vital that the link exist between vision and the chairperson ability to powerfully communicate and propagate to the entire organization.

In the new era of globalization, banking sector in India has witnessed tremendous changes at structural and organizational levels. Banking sectors are the leaders in playing a key role in implementing the best management and business practices. While studying the performance of the banks under different leaders we kept certain objectives for the study, and the study is in aligned to the set objectives.

\section{References}

1. Alvesson, M. \& Karreman, D. (2000). Varieties of discourse: On the study of organizations through discourse analysis. Human Relations, Vol. 53(9):1125-49.

2. Borins, S. (2002): Leadership and innovation in the public sector-

Leadership \& Organization Development Journal, emeraldinsight.com

3. Brown E Michael, K Linda. David Trevino, Harrison A. (July 2005): Organizational Behavior and Human Decision Processes- Elsevier, Issue 2, Pages 117-34. Volume 97.

4. Conger Jay A, Kanungo, Rabindra N. (1987): A Behavioral Theory of Charismatic Leadership in Organizational Settings: Academy of management review, amr.aom.org. doi: 10.5465/AMR.1987.4306715

5. Dicken P Global shift (2007): Mapping the changing contours of the world economy

6. Dilulio, J. J. (1990), Leadership and innovation: A biographical perspective on entrepreneurs in government, edited by Jameson W. Doig and Erwin C. Hargrove. Baltimore, MD: The Johns Hopkins University Press, 1987, 459 pp. Price: $\$ 39.50$ cloth. J. Pol. Anal. Manage. 9:116-26.

7. EI Ejere, UD Abasilim (2013): The Journal of Commerce, covenantuniversity.edu.ng

8. Evans BO, Akash SB, Oyagi B (2015): Impact of transactional and transformational leadership styles on organizational performance: empirical evidence from Nigeria -The Journal of Commerce, Vol. 5, No.1

9. Ferlie E, Hartley J , Martin S (2003): Changing public service organizations: current perspectives and future prospects, British Journal of Management, Wiley Online Library

10. Ferrier WJ, Smith KG, Grimm CM (1999): The role of competitive action in market share erosion and industry dethronement: A study of industry leaders and challengers - Academy of management journal, amj.aom.org

11. F Ostroff (1999): The horizontal organization: What the organization of the future looks like and how it delivers value to customers, - Oxford University Press.

12. Hal G. Rainey, Barry Bozeman; Comparing Public and Private Organizations: Empirical Research and the Power of the A Priori, Journal of Public Administration Research and Theory, Volume 10, Issue 2, 1 April 2000, Pages 447-70, https://doi.org/10.1093/oxfordjournals.jpart.a024276

13. Hart, R.P. (1984b). Verbal style and the presidency: A computer-based analysis. New York: Academic.

14. Hart, R.P. (2000). DICTION 5.0: The text-analysis program. Thousand Oaks, CA: Sage.

15. Hitt, M. A., \& Ireland, R. D. (2002). The essence of strategic leadership: Managing human and social capital. 
Journal of Leadership \& Organizational Studies, 9(1),315. Retrieved May 28, 2006, from ProQuest database.

16. Jagadhri (Mar 2012): Training and Development Policies of Public and Private Banks-A case Study of Some Selected Banks in Karnataka International Journal of Marketing and Technology; 2.3, page no.183-204.

17. Kaur R (2013): Transformational and transactional leadership behaviour in selected public and private sector banks in Chandigarh, International Journal of Engineering and Management I.J.E.M.S., VOL.3(2).

18. Kirkpatick SA, Locke EA (1991): Leadership: do traits matter? - The executive Macesich, George(2000). Issues in money and banking. Westport, Conn.: Praeger, 2000.

19. Mayring, P. (2000). Qualitative content analysis. Forum: Qualitative Social Research, 1(2). http://www.qualitativeresearch.net/fqs-texte/2-00/02-00mayring-e.htm Google Scholar.

20. McLaughlin, Veritas Dublin (1999): Distinctiveness and the Catholic school-balanced judgement and the temptations of commonality- Catholic Education. InsideOut/Outside-In, Mehta S (April 2016): A Review Paper on leadership styles of managers among public and private sector banks and its relationship with other constructs - International Journal of New Innovations in Engineering and Technology- Volume 4 Issue 4.

21. Moore, David R., Cheng, Mei-I, Dainty Andrew R.J "Competence, competency and competencies: performance assessment in organizations", Work Study, Vol. 51 Issue: 6, pp.314-9.

22. Morris, M., \& Peng, K. (1994). Culture and causes: American and Chinese attributions for social and physical events. Journal of Personality and Social Psychology, 67, 949-71.

23. Noe RA, Hollenbeck JR, Gerhart B, Wright PM (2006) Gaining a competitive advantage -Human resource management

24. Sitkin SB (1992): Learning through failure: the strategy of small losses, - Research in organizational behavior, Volume 14, page no 231-66.

25. Satu Elo, Maria Kaariainent, Outi Kanste, Tarja Polkki, Kati Utriainen, and Helvi Kyngas (2014) : Qualitative Content Analysis: A Focus on Trust worthiness. SAGE Open January-March 2014: 1 -10 @ The Author(s) 2014 DOI: $10.1177 / 2158244014522633$ sgo.sagepub.com

26. Sullivan J (2006): Addressing difference as well as commonality in leadership preparation for faith schools-Journal of Education and Christian Belief, ice.sagepub.com

27. Taylor \& Francis (1999): Two decades of research and development in transformational leadership, BM Bass European journal of work and organizational

28. Turner J. Rodney, Lille (2005): A Literature Review: The Project Manager's Leadership Style; As a Success factor On Projects: by the Project Management Institute Vol. 36, No. 1, page no 49-61.

29. Voon ML, Lo MC, Ngui KS, Ayob NB (2011): The influence of leadership styles on employees' job satisfaction in public sector organizations in MalaysiaInternational Journal of Business, Management and Social Sciences Vol. 2, No. 1, page no. 24-32.

30. Weber, R.P. (1990) Basic Content Analysis. 2nd Edition, Sage, Newbury Park.

31. Wong SHY, Yang H, Lu S, Bharghavan V (2006):

Robust rate adaptation for 802.11 wireless networks Proceedings of the 12th edition, dl.acm.org 